\title{
Blurring of Wrinkles Through Control of Optical Properties
}

\author{
Naoki Nakamura*; Yutaka Takasuka; and Isamu Takatsuka*
}

\begin{abstract}
To develop a novel makeup which is effective in making wrinkles less visible, optical properties of the makeup compornents and their mixtures were systematically studied.

It was discovered that within a specific composition range, it was possible to produce a makeup more effective in making wrinkles much less visible than possible with other mixtures. The composition of this "SOFT FOCUS MIXTURE" was found to be strongly dependent on the optical properties as well as the ratio of the powder to the oil. Two major factors found to contribute to the reduction of wrinkle visibility are: (a) Optical blurring of the outlines of wrinkles, and (b) Reduction in the differerence of lightnesses due to diffuse reflection. The first is strongly dependent on the concentration of the oil phase while the second is affected by the gloss of the powder. By optimizing these two factors, effective makeup have been prepared to make wrinkles less apparent.
\end{abstract}

\section{1. 諸 言}

女性顔面の皮フトラブルに関しては種々考克られる が, シワは常にそれらの内で重大な悩みとして存在し, 加龄に伴い増大するるのである。目に見觉る皮膚トラブ ルを大まかに分類するならば, 形態トラブル（皮膚の四 凸に関するすのでシワ, 毛穴, キィの荒さ等が含まれ る）と色調トラブル（皮フの色変化に関するものでシ ミ，ソバカス，赤ら顔等が含まれる）に2分されよら。 本報告は上記のらら形態トラブルに注目し, メークアッ プによってこれらを目立たなくする方法に関したもので める。

従来, トラブル対応型のメークアップ料は主に二酸化 チタンに代表される高屈接率顔料の配合により皮膚を隠 蔽するタイプのものであった。しかしこのタイプは色調

* ポーラ化成工業侏静岡研究所：静岡市弥生町 648 ポーラ化成工業侏横浜研究所 : 穔浜市高島台27-1

* R \& D Laboratories POLA Corporation; 648 Yayoi-cho, Shizuoka

R \& D Laboratories POLA Corporation; 27-1

Takashimadai Kanagawaku, Yokohama
トラブルに関しては効力を有してはいるものの, 形態ト ラブルに対しては充分な效果を有しているとは言い難 い。このタイプのメークアップ料で無理に形態トラブル を隠そうとすることで, 逆に経時での表情筋の動きによ ってトラブル部分が目立ったり，いわゆる“厚化栍”に なる場合も多い。つまり形態トラブル対応《执いては隠 蔽といら切り口は妥当ではないと考光られる。

本研究はメークアップ料に配合される種々の粉体類及 び化粧膜に関して, それらの光学的特性 (隠蔽力も勿論 この中の 1 つであが）を幅広く検討することで形態卜 ラブル対応のアプローチを行い，興味深い結果を得たの でここに報告する。

\section{2. 方 法}

化粧膜は数 $\mu$ の厚さで皮膚上に形成されていると言わ れるが，なるべくこの状態に忠実でありたいことから， ドクターブレード $(0.3 \mathrm{mil} \sim 0.5 \mathrm{mil})$ により薄膜を作成 しその光学的特性を把握する方法を取った。薄膜の組成 はメークアップ料であることを考慮し粉体及び粉体と油 剂との混合物を中心に実施し, フィルム作成時の粘度調 節を揮発性シリコン油にて行った。 
直進透過光 (DT) を日立340型分光光度計, 拡散透過 光 (TT) を同機種積分球ニニットにより測定した。反射 光 $(R)$ を村上色研製 CMS-1200 型色彩計にて測定し た。顔料に白色粉体類を使用したことから, 透過率, 反 射率ともに $560 \mathrm{~nm}$ の值を代表值とすることとした。

日本電色製変角光沢計 (GLoss Meter) 飞よって $75^{\circ}$ 入射光に対する粉体薄膜の $75^{\circ}$ 反射率及び $45^{\circ}, 60^{\circ}$ 各 入射光に対する $0^{\circ} \sim 75^{\circ}$ までの $5^{\circ}$ 每の反射率を測定し, 粉体の光沢強度, 表面反射パターンの推定を行った。

拡散反射型の粉体の開発: 拡散反射型の表面反射ハタ ーンを有する粉体をタルク上にアクリル系ポリマーをコ 一トすることで作成した。タルク及び開始剂を水中に分 散し $60^{\circ} \sim 80^{\circ} \mathrm{C}$ に加温しつつモノマーを徐々に添加し, ポリマーをタルク表面にコーティングさせた後, 万過, 洗浄乾燥を行った。タルク重量の60～80\%のモノマー量 添加で重合収率は90 95\%であり, 乾燥後の残存モノマ 一は 40〜80ppm と低率であった。

試作したケーキ状ファンデーションの実使用テストを

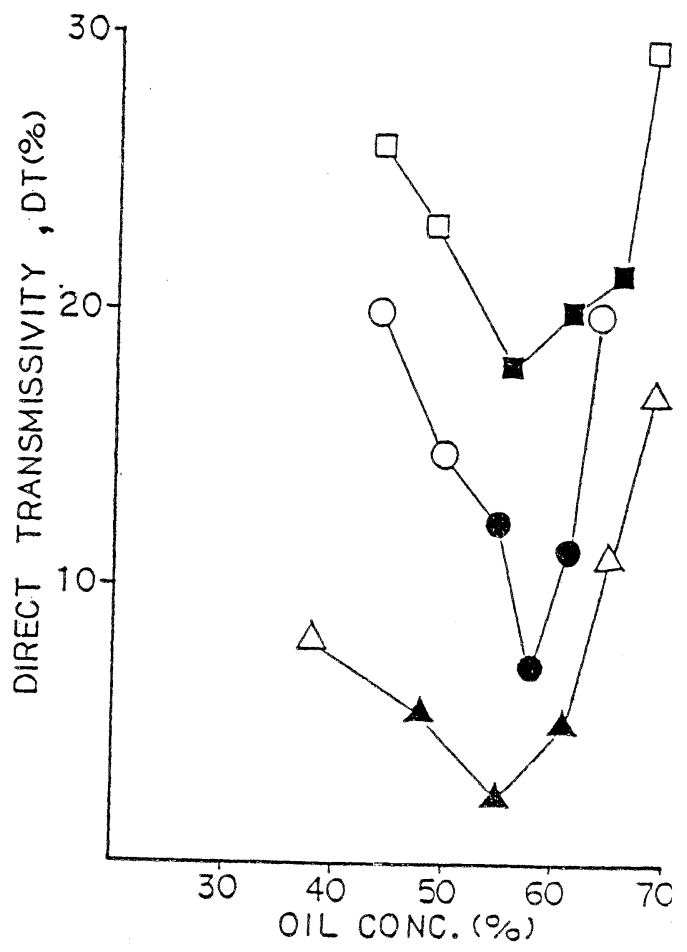

Fig.-1 DT curves of three mixtures

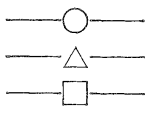
Acrylic coated talc Spherical silica Spherical calcium silicate
女性パネル 120 名の顔面にて実施し, 全顔写真及び等倍 の目の周囲の写真撮影を行った。

\section{3. 結 果}

粉体と油剤との混合物薄膜の DT 及び R のカーブを Fig.-1, Fig.-2 飞示す。DT は油剂の増量に伴い減少 していくがある一定のゾーン (図中の黒点)で極少を示 しその後上昇する。Rは油剤の増量と伴に減少していく がその途中に和いて, 減少が止るか, ゆるやかになるゾ ーンを持つ。このゾーン（黒点で示す）と，DT の黑点 のゾーンは, 同一の粉体, 油剤の系であるならばほぼ一 致し, 粉体の吸油量によって左右にシフトするるのであ った。この黒点部分の混合物薄膜は一つの特徵的な光学 的性質を持つ。Fig.-3，Fig。-4 は細い2 本の黑線上に スライドガラスに塗布された鼬合物薄膜を重ねた際の写 真である。Fig.-3 の薄膜は DT, R カーブでの黒点で 示されたゾーンの混合物であるが，この場合薄膜の下の 黒線の輪郭がぼけて，2本の線の区別が不可能になって

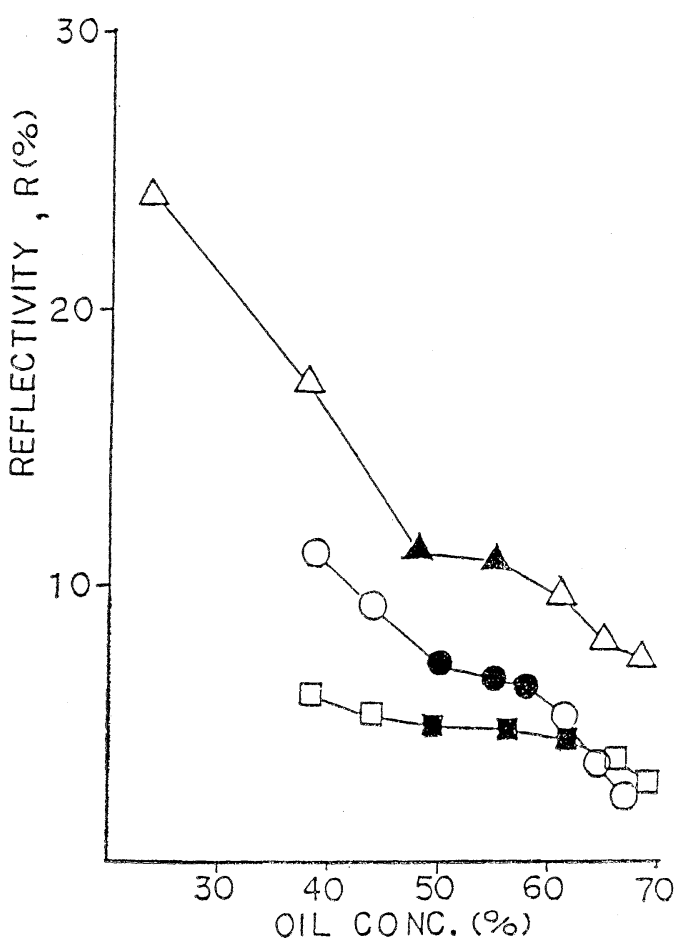

Fig. - 2 R curves of three mixture

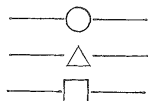
Acrylic coated talc Spherical silica Spherical calcium silicate 


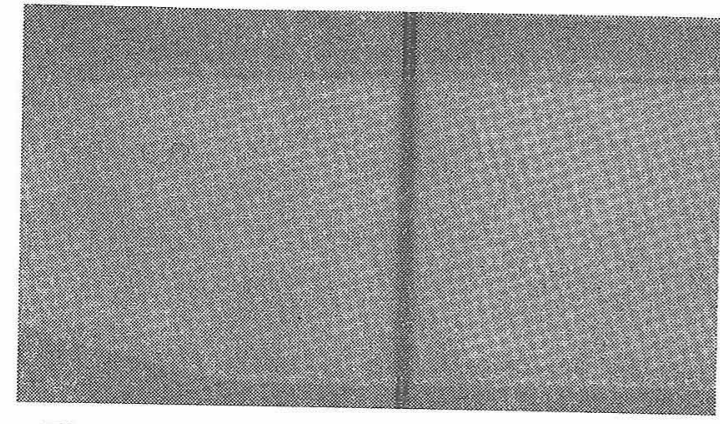

Fig.-3 Thin layer of SFM Causing blurring of the line

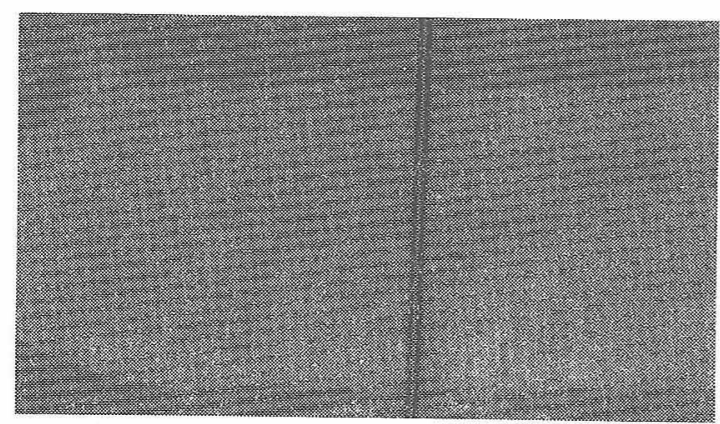

Fig. -4 Thin layer of a mixture (non SFM) Causing no blurring effect

いることが判る。黑点のゾーン以外の混合物 (Fig.-4) では黑線の区別は明確に判る。この現象から筆者らは Fig.-3 の性質示す混合物を,ソフトフォーカスミック ステャーと名付けた。さらにンフトフォーカスミックス チャーのゾーンに括いてはTTのカーブにる特徴のある ことが判明した (Fig.-5)。

混合物中の油郕の增量飞伴いTTはソフトフォーカス ミクスチャーのゾーン（黒点で示す）では極大值を示し ている。結局このゾーンに粘いては, DT が小さく TT が大であることになる。

ソフトフォーカスミクスチャーは下地の輸郭をぼかす 効果が確認されたため，これ学皮膚上に塗布した際にほ トラブル部分の輪郭がぽかされ，目に見觉にくくなるこ とが期待され，実際に成人男性の手の甲の部分に和いて 艺の証明を行った，Fig.-6，Fig.-7，Fig.-8 は手の甲の 同一部分の 2.5 倍の拡大写真である。中央の Fig. -7 は ソフトフォーカスミクスチャーを塗布した場合であり， Fig.-6 はこれより油剤の少いゾーンの混合物，Fig.-8 ほ油剤の多いゾーンの混合物を各々塗布した場合で岁 る。ソフトフォーカスミクスチャーを塗布した場合は明

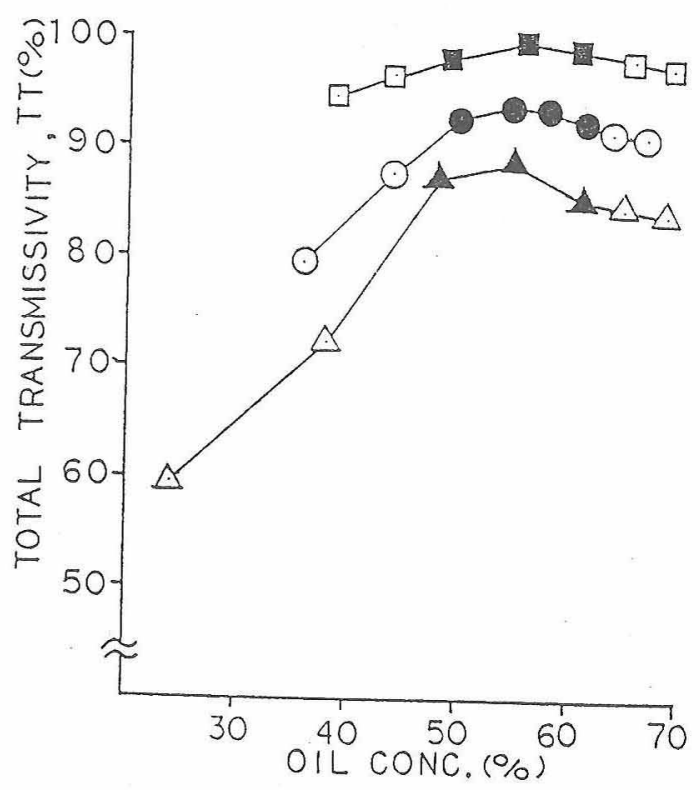

Fig.-5 TT curves of three mixtures - - - Acrylic coated talc $\longrightarrow \triangle-$ Spherical silica $\square \square$ Spherical calcium silicate Polydimethyl siloxane was used as an oil

らかと溝部分が目立たなくなっていることが判る（粉体 に球状シリカ, 油剤㷸リジメチルシロキサンを使用し た)。

メークアップ料には非常に多種にわたる粉材素材が使 用されているが，これらの粉体の種類によって形態トシ ブル隠し效果に差があるか否かにつき検討した結果與味 ある事実が判明した。

Fig. - 9, Fig.-10, Fig.-11 は各々球状シリカ，タル ク粉, チタンコートマイカのポリジメチルシロキサンと の混合物を手の甲に塗布した際の 2.5 倍拻大写真であ る。混合物はソフトフォーカスミクスキャーのゾーンで 作成したものである。

これらの写真からは, 球状シリカが非常に效果を持 ち, チタンコートマイカは皮㶚が目立ち, タルク粉はほ ぼその中閒であることが示される。

筆者らは，この形態トラブルを隠す度合について10点 満点の評点をつ梳, 球状シリカの場合を10点, タルク粉 を5点, チタンコートマイカを 0 点とし，この設定を基 準とし,多種の粉体についての評価を実施した。Table-1 は矢の結果である。ここでRs 粉体膜の $75^{\circ}$ 入射光に対与る $75^{\circ}$ 反射光強度, $T_{r}$ はン 


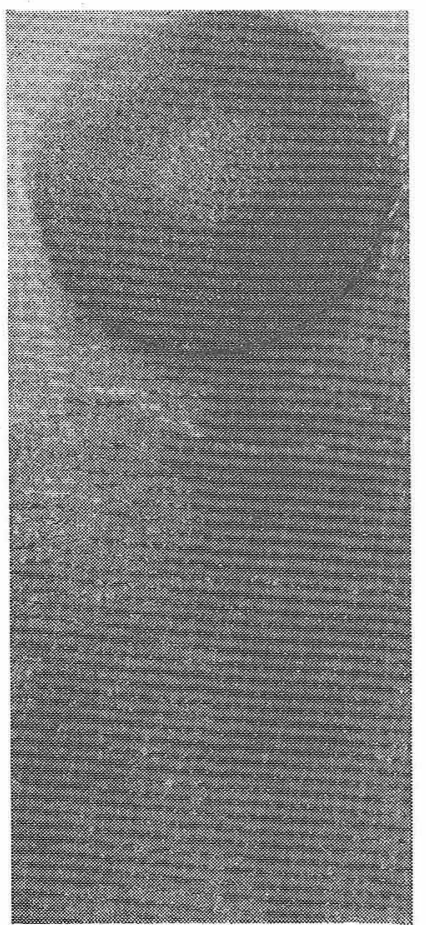

Fig. -6

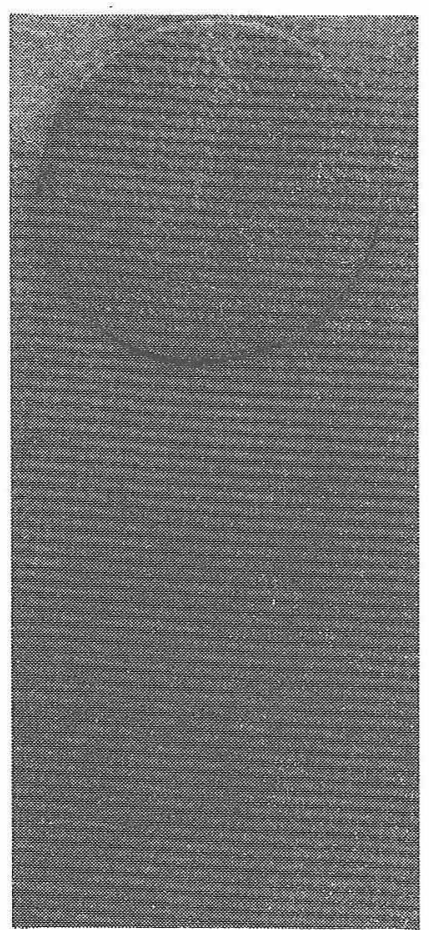

Fig. -9 (Spherical silica) grade 10

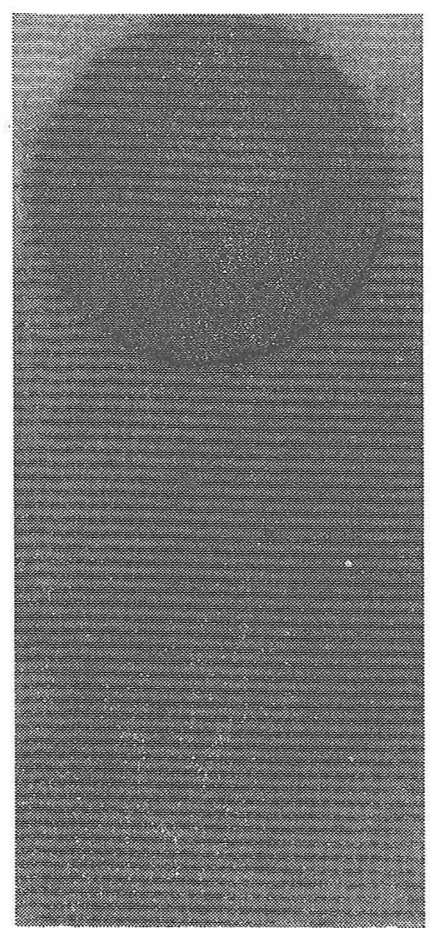

Fig.-7

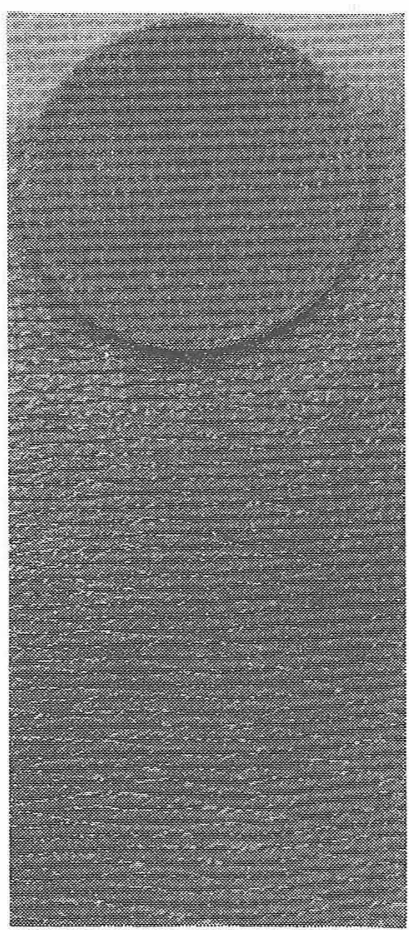

Fig.-10 (Talc) grade 5

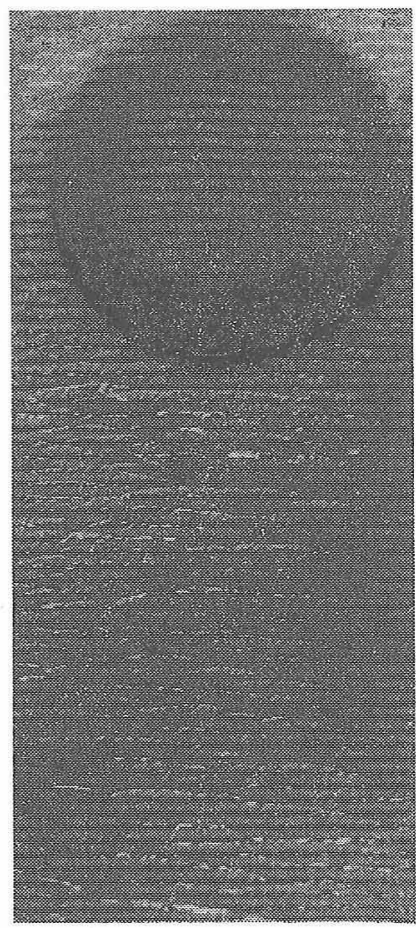

Fig.-8

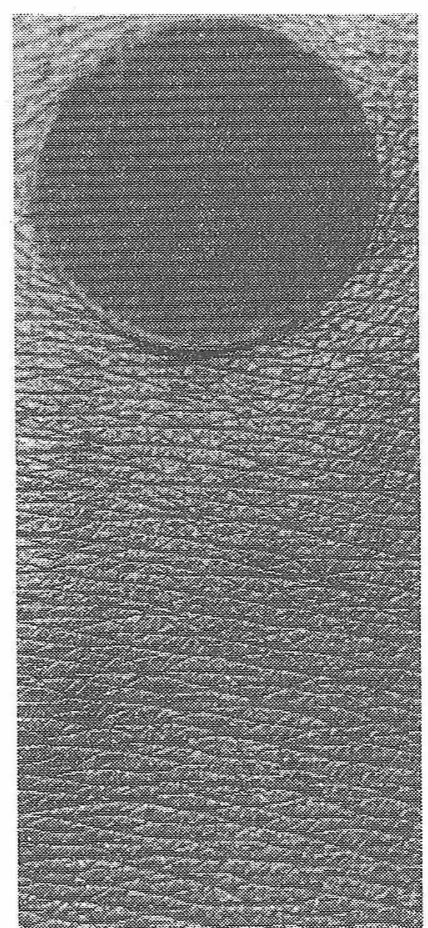

Fig.-11 (Mica coated $\mathrm{TiO}_{2}$ ) grade 0 
Table-1

\begin{tabular}{lcccr}
\hline \multicolumn{1}{c}{ pigments } & $\mathrm{R}_{\mathrm{s}}$ & $\mathrm{G}$ & $\mathrm{T}_{\mathrm{r}}$ & grade \\
\hline Spherical silica & 2.742 & 4.605 & 0.145 & 10.000 \\
Spherical nylon & 2.535 & 4.828 & 0.216 & 10.000 \\
Benzoguanamine powder & 2.250 & 4.828 & 0.239 & 9.000 \\
Micro crystal cellulose & 2.908 & 4.828 & 0.322 & 8.500 \\
Acrylic polymer coated talc & 2.208 & 4.269 & 0.371 & 8.000 \\
Spherical acrylic polymer 1 & 2.867 & 4.828 & 0.290 & 8.000 \\
Spherical calcium silicate & 3.014 & 4.828 & 0.258 & 8.000 \\
Spherical acrylic polymer 2 & 1.936 & 4.200 & 0.191 & 7.000 \\
Kaolin & 1.796 & 3.912 & 0.205 & 6.500 \\
Titanium dioxide (anatase) & 0.564 & 3.772 & 0.840 & 3.000 \\
Talc (small partikles) & 2.323 & 3.073 & 0.175 & 5.000 \\
Talc (large particles) 1 & 2.645 & 2.996 & 0.286 & 4.500 \\
Cericite & 2.364 & 2.513 & 0.166 & 4.000 \\
Talc (large particles) 2 & 2.631 & 2.513 & 0.276 & 3.500 \\
Mica & 2.343 & 2.257 & 0.297 & 2.500 \\
Titanium dioxide coated mica 1 & 0.794 & 2.808 & 0.645 & 2.000 \\
Titanium dioxide coated mica 2 & 0.903 & 2.211 & 0.626 & 1.000 \\
Titanium dioxide coated mica 3 & 1.725 & 1.888 & 0.419 & 0.000 \\
\hline R : & & & & \\
\hline
\end{tabular}

$\mathrm{R}_{\mathrm{S}}$ : minus natural logarithms of $\mathrm{R}$ in SFM

$\mathrm{G}$ : minus natural logarithms of $\mathrm{GS}^{\circ} 5^{\circ}$ of dry pigments

$\mathrm{T}_{\mathrm{r}}$ : minus natural logarithms of $\mathrm{TT}$ without $\mathrm{DT}$ in $\mathrm{SFM}\left[\mathrm{T}_{\mathrm{r}}=-\ln (\mathrm{TT}-\mathrm{DT})\right]$

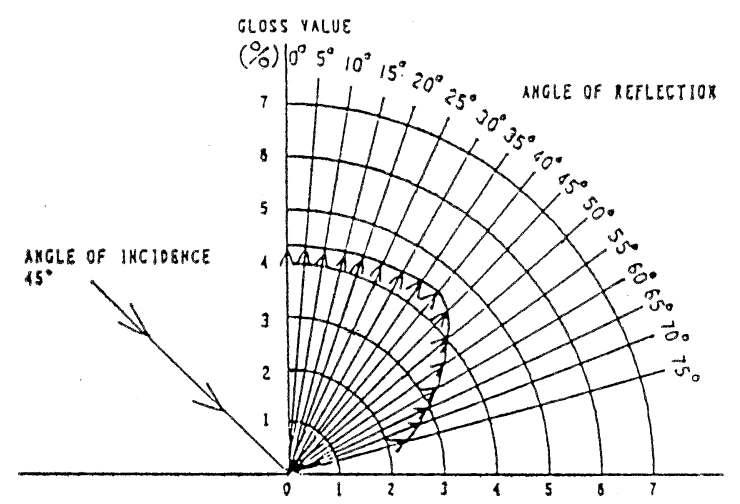

Fig.-12 Refletion pattern of Acrylic Coated Talc. This pattern is likely to diffese reflection and regular reflection $\left(45^{\circ}\right)$ is not very strong. The average GLOSS VALUE is 3.93 . G is 4.269

フトフォーカスミクスチャー薄膜の TT と DT の差の 各々自然対数の負の值である。グレードは10点法の評点 を示す。

これらの結果から，グレードを目的变数とし重回滞分

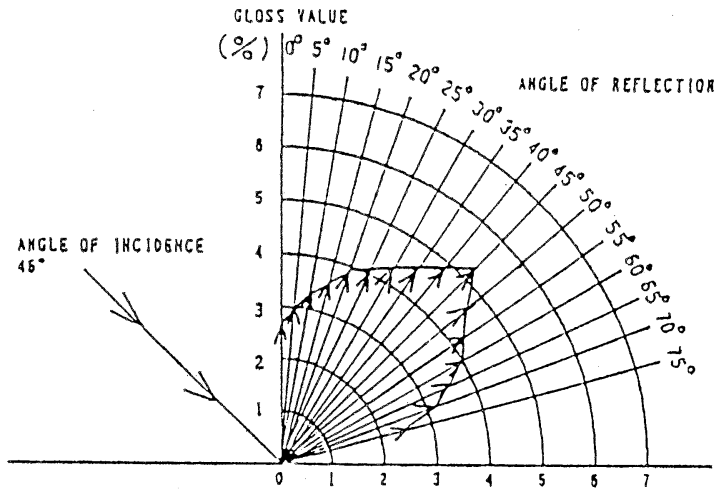

Fig.-13 Reflection pattern of Talc. Regular reflection $\left(45^{\circ}\right)$ is strong. The average of GLOSS VALUE is $3.94 \mathrm{G}$ is 3.073

析を行った結果が次式である。

$$
\mathrm{Y}=-1.237+2.386 * \mathrm{G}-5.663 * \mathrm{~T}_{\mathrm{r}}
$$

標準化された場合の係数は $\mathrm{G}$ につて0.823， $\mathrm{T}_{\mathrm{r}}$ につ いて -0.346 となり, 重相関倸数は 0.984 を示した。

つまり形態トラブル隠しについては, 粉体の光沢と, 
TT そ DT の差の 2 者が重要であり, 中でる粉体の光沢 は強い影響を持ら, 光沢の低い粉体がより有効であると いら結果である。

光沢が低いといらことは粉体表面での光正反射が弱い ということですある。

箨者らは粉体表面の光正反射を弱めることで形態トラ ブルが目立たなくなることを確認するため，タルク粒子 上Kアクリル系ポリマーをコーティングした複合顔料を 作成し，無処理のタルクとの比較を行った。

Fig.-12，Fig.-13 は両者の光反射パターンを示す。 Fig.-13 ほ無処理のタルクのパターンであるが反射光は $45^{\circ}$ Kピークを持ら正反射が強いことが判る。Fig。一-12 はアクリル系ポリマーをコーティングしたタルクのパタ ーンであるが, $45^{\circ}$ にピークが無く拡散反射に近いこと

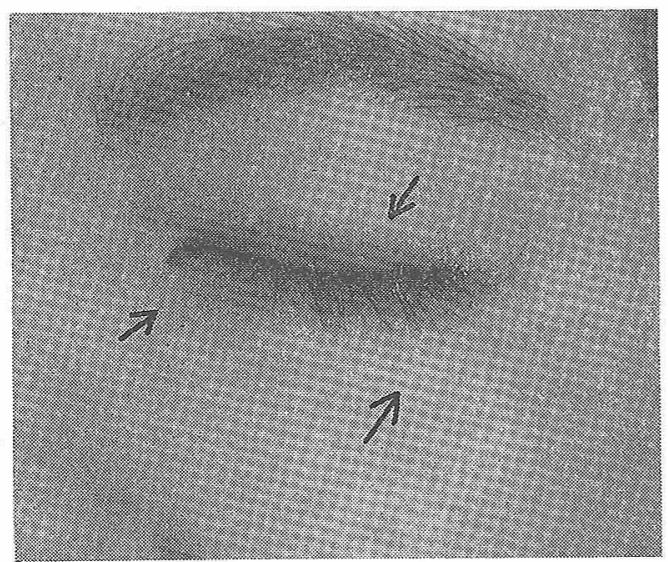

Fig.-14 SFM of Acrylic Coated Talc applied on 22 years old woman's face

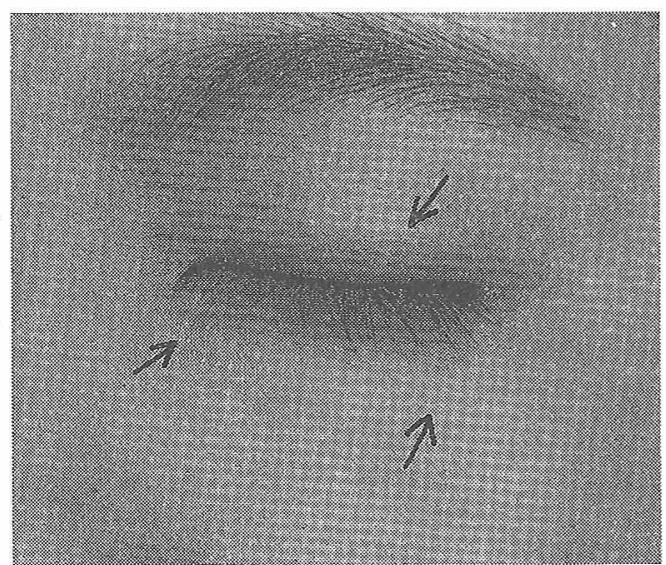

Fig.-15 SFM of Talc applied on same face as Fig. -14
が判る。

さらに両粉体についてりフトフォーカスミクスチャー を作成し顔面炕塗布した結果を Fig.-14〜Fig.-17 亿示 す。これらの写真は目の回りの小ジワの見方炕大きな 差があり，アクリル系ポリマーをコートした拡散反射型 の複合顔料を使用した場合，小ジワが見えにくくなるこ とを示している。

次にこの複合顔料学用いたソフトフォーカスミクスチ ヤーからなる試作品ケーキファンデーションによって, 実際に女性パネラーの顔面にてテストした結果を Fig.18, Fig.-20, Fig.-22 飞示す。

対照として市販ケーキファンデーションを同一顔面に 染布した結果を Fig.-19，Fig.-21，Fig.-23 に各々示 す。

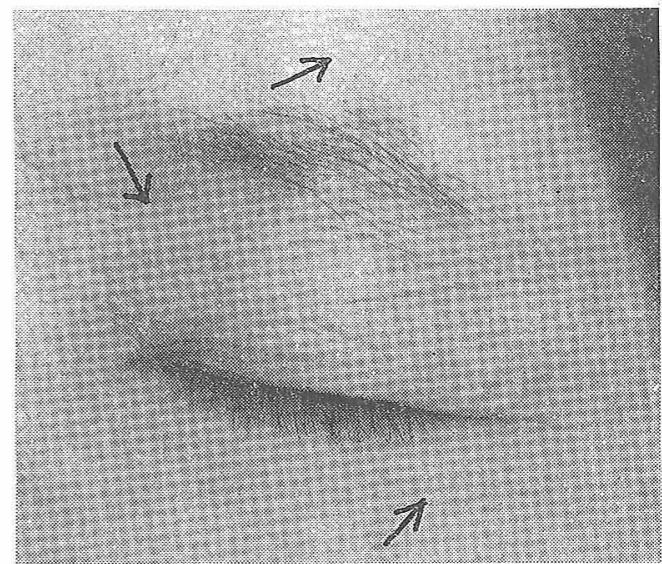

Fig.-16 SFM of Acrylic Coated Talc applied on 48 years old woman's face

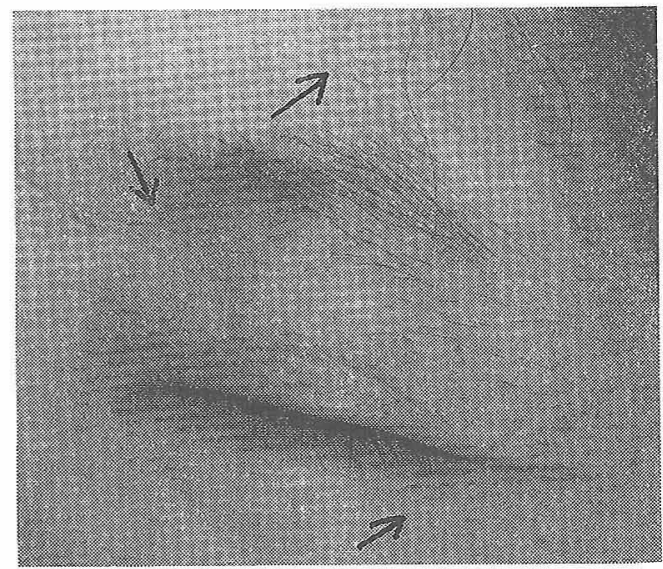

Fig.-17 SFM of Talc applied on same face as Fig. -16 


\section{粉体の光学的研究とシワ隠し效果}

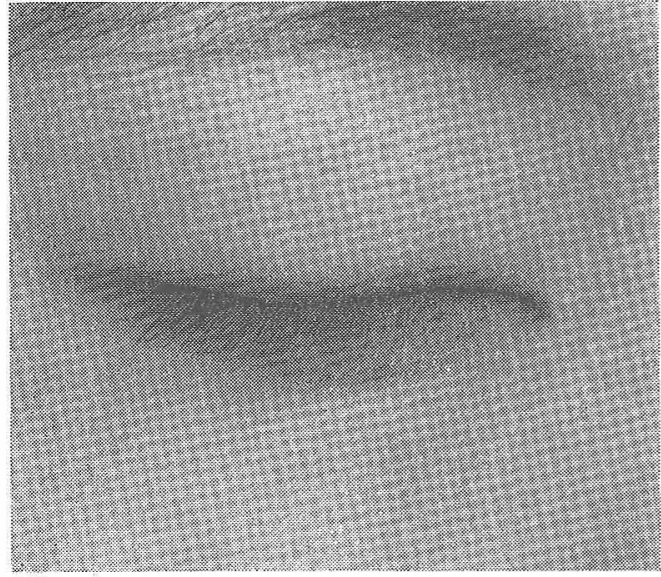

Fig.-18 Experimental Foundation using SFM

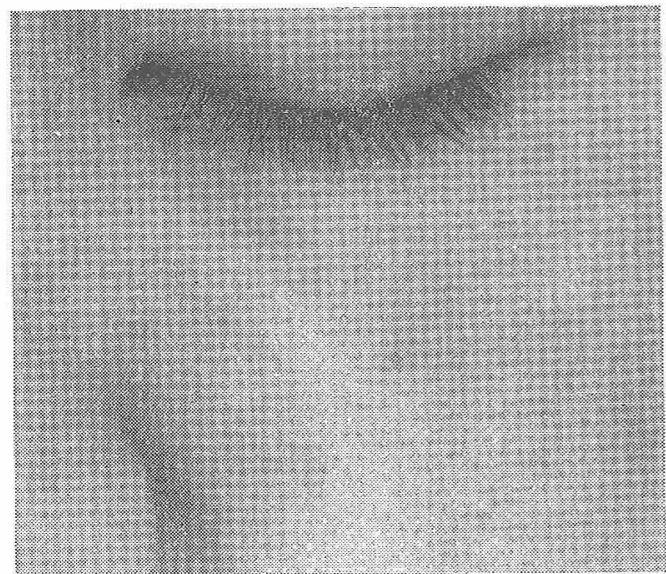

Fig.-20 Experimental Foundation using SFM

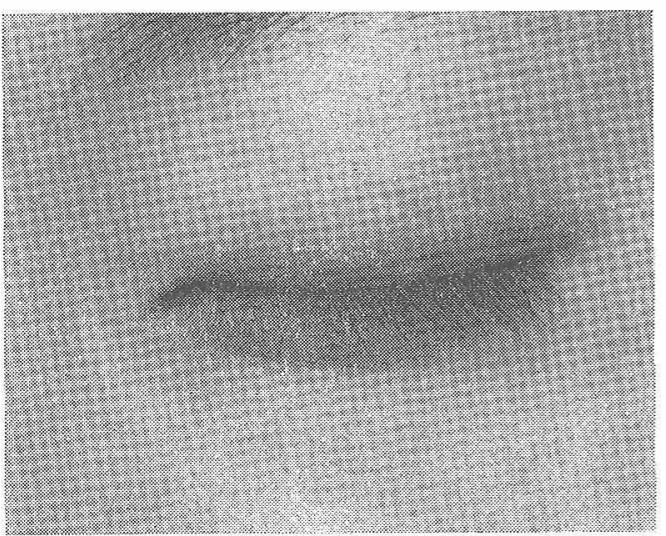

Fig.-22 Experimental Foundation using SFM

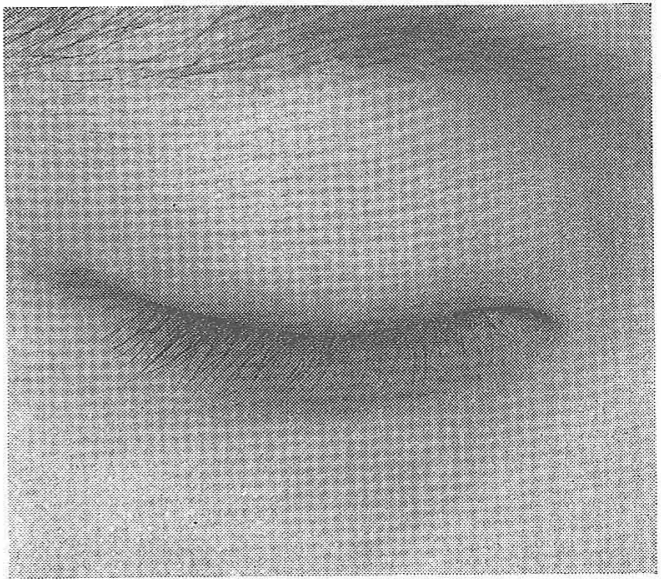

Fig.-19 Commercial Foundation A, applied on the same subject shown in Fig.-18

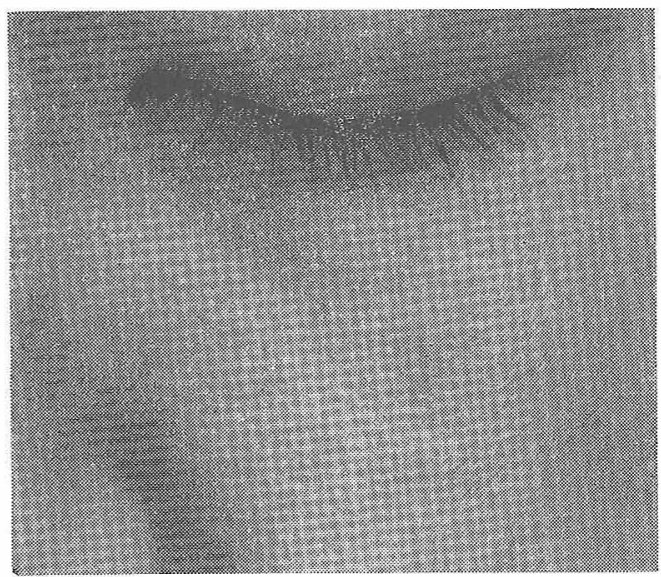

Fig.-21 Commercial Foundation A, applied on the same sublect shown in Fig.-20

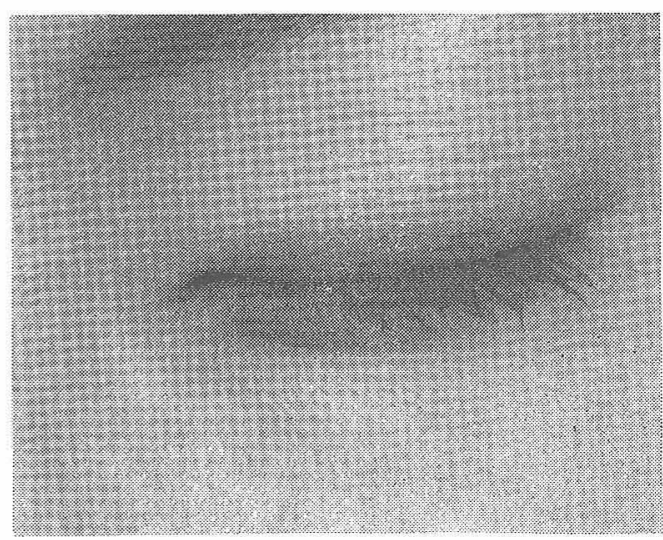

Fig.-23 Commercial Foundation B, applied on the same subject shown in Fig.-22 
試作品ケーキファンデーションに括いては, 目の回り の小ジワ, 頓の毛穴, キ>の荒さ等が効果的に目立たな くなっていることが判る。

\section{4. 考 察}

粉体と油剤との混合物は，その混合比のある割合にて Fig.-1, Fig.-2 の様な光学的性質を持ち, このものは下 地の輪郭をぼかす効果を持っていた(ソフトフォーカス ミクスチャー)。ソフトフォーカスミクスチャーのゾー ンでは DT が極小を TT 極大を示しその差 TT-DT は 大きくなっている。 TT-DT が大きくなるにつれ，相 対的江直進透過光が減少し, 拡散透過光が增大するわけ で, 混合物薄膜によって光が曲げられることになる。こ のため下地の物体の境界線は不鮮明となり輪郭が汭けて 見光ることになる。

ソフトフォーカスミクスチャーは形態トラブルの輪部 をぼかすため, 形態トラブルが目立たなくなることが確 認されたが, 全ての種類の粉体のソフトフォーカスミク スチャーがその効果を持つものではないことが判明し た。その効果の強さは顔料の光沢に大きく影響され, 光 沢の低いもの程形態トラブルが見光にくくなることが証 明された。光沢の強い粉体は肌上に塗布した際皮丘部分 の明度が上昇し, 皮溝等の肌上の凹部との間の明度差が 大さくなるため形態トラブルが目立ち易くなると考兄ら れる。逆に光沢の低い, 粉体程明度差は減少するため形態 トラブルは目立ちにくくなってくる。Fig.-9, Fig.-10,
Fig.-11 からもとれが確認される。 光沢の低い粉体は表面の光正反射が弱く, 拡散反射を すると考光られる。筆者らは実際にタルク粒子をアクリ ル系ポリマーでューティングすることで拡散反射型複合 顔料を作成し，これを使用したりフトフォ一カスミクス チャーが著しく形態トラブルを見觉にくくすることを確 認した。もちろん光沢の低い顔料を使用してもソフトフ オーカスミクスチャー以外の混合物では形態トラブルを 見光にくくする効果が弱化することは，Fig.-6, Fig.-7, Fig.-8 からも明らかである。

メークアップ料によって形態トラブルを見えにくくす るためには，2つの要素を満足させることが重要である と判明した。

つまり

(a)……形態トラブルの輪郭をぼかすこと

(b)……肌の凹凹間の明度差を減少させること の 2 要素である。

(a)はソフトフォーカスミクスチャーによって満足さ れ，(b)は拡散反射型の粉体を使用することで満足され る。言い換れば(b)は配合される原料自体の特性であり(a) はその原料の配合方法に関する要素である。形態トラブ ル対応のメークアップ料は，そのために適した原料をそ のために適した方法で配合することによって效果的に達 成されたものである。

（第14回 IFSCC バルセロナ大会発表論文 昭和62年 3 月 31 日受理) 